Supporting Information for:

\title{
Mono- versus bis-chelate formation in triazenide and amidinate complexes of magnesium and zinc
}

\author{
Nonsee Nimitsiriwat, Vernon C. Gibson, ${ }^{*}$ Edward L. Marshall, ${ }^{*}$ Pittaya \\ Takolpuckdee, Atanas K. Tomov, Andrew P. J. White, David J. Williams, Mark \\ R. J. Elsegood and Sophie H. Dale
}

Imperial College London, Department of Chemistry, South Kensington Campus, London SW7 2AZ, United Kingdom;

Loughborough University, Department of Chemistry, Loughborough LE11 3TU, United

Kingdom 


\section{Contents}

Crystallographic Analysis of Complexes 1, 2, 3, 4, 5, 6, 8 and 10.

Figure S1. The molecular structure of complex 1 . 5

Figure S2. The molecular structure of the $C_{2}$-symmetric complex 2 . 5

Figure S3. The molecular structure of complex 3 . 6

Figure S4. The molecular structure of one (I) of the two independent 6 complexes present in the crystals of $\mathbf{4}$ (30\% probability ellipsoids).

Figure S5. The molecular structure of one (II) of the two independent complexes present in the crystals of 4 .

Figure S6. The molecular structure of one (II) of the two independent complexes present in the crystals of 4 (30\% probability ellipsoids).

Figure S7. Overlay of the two independent complexes (I and II) present in the crystals of 4.

Figure S8. The molecular structure of complex 5.

Figure S9. The molecular structure of one (I) of the two independent complexes present in the crystals of $\mathbf{6}$.

Figure S10. The molecular structure of one (I) of the two independent complexes present in the crystals of $\mathbf{6}$.

The molecular structure of complex 6

Table S1. Selected bond lengths $(\AA)$ and angles $\left(^{\circ}\right)$ for the two independent complexes (6-I and 6-II) present in the crystals of 6.

Figure S11. The molecular structure of 11.

Table S2. Crystal Data, Data Collection and Refinement Parameters for compounds $1,2,3,4,5,6,9$ and 11.

Figure S12. Overlay diagram of the $\mathrm{L}^{1} \mathrm{Zn}$ fragments of complex 1 with the $\mathrm{L}^{2} \mathrm{Zn}$ fragment of complex 3 .

Figure S12. Overlay diagram of the $\mathrm{L}^{1} \mathrm{Zn}$ fragment of complex 1 with the $L^{3} \mathrm{Zn}$ fragment of complex 8 . 


\section{Crystallographic Analysis of Complexes 1, 2, 3, 4, 5, 6, 8 and 10}

Data for complexes $\mathbf{1}, \mathbf{3}, \mathbf{5}, \mathbf{6}$ and $\mathbf{8}$ were collected on a Bruker AXS SMART 1000 $\mathrm{CCD}$ area-detector diffractometer, at $150 \mathrm{~K}$, using graphite-monochromated $\mathrm{Mo}-\mathrm{K}_{\alpha}$ radiation and narrow frame exposures $\left(0.3^{\circ}\right)$ in $\omega$. Cell parameters were refined from the observed $(\omega)$ angles of all strong reflections in each data set. Intensities were corrected semi-empirically for absorption, based on symmetry-equivalent and repeated reflections. The structures were solved by direct methods (Patterson synthesis for $\mathbf{1}, \mathbf{5}$ and $\mathbf{6}$ ), and refined on $F^{2}$ values for all unique data by full-matrix least-squares. Table S1 gives further details. All non-hydrogen atoms were refined anisotropically. For 1 the methyl groups on the ${ }^{i} \operatorname{Pr}$ at $C(7)$ and $C(33)$ and the whole ${ }^{\mathrm{i}} \operatorname{Pr}$ group at $\mathrm{C}(19)$ were disordered over two sets of positions. For 3 the whole ${ }^{\mathrm{i}} \mathrm{Pr}$ groups at $\mathrm{C}(12)$ and $\mathrm{C}(24)$ and the six ring atoms starting at $\mathrm{C}(15)$ were disordered over two sets of positions. The structure of $\mathbf{5}$ contains half a molecule of heptane per $\mathrm{Zn}_{4}$ complex, disordered over an inversion centre. In 6 the Et group at $\mathrm{Zn}(4)$ is disordered over two sets of positions. In each case of disorder restraints were applied to assist geometry and anisotropic displacement parameters. Programs used were Bruker AXS SMART and SAINT for diffractometer control and frame integration, ${ }^{\mathrm{S}}$ Bruker SHELXTL for structure solution, refinement and molecular graphics, s2 and local programs.

Data for complexes $\mathbf{2}$ and $\mathbf{1 0}$ were collected on an Oxford Diffraction Xcalibur 3 diffractometer at $173 \mathrm{~K}$ using graphite-monochromated Mo-K $\alpha$ radiation, whilst those for complex 4 were collected on a Siemens P4 rotating anode diffractometer at $203 \mathrm{~K}$ using graphite-monochromated $\mathrm{Cu}-\mathrm{K} \alpha$ radiation. Refinements were by fullmatrix least-squares based on $F^{2}$ using the SHELXTL program system. The C(10) isopropyl moiety in the structure of the $C_{2}$-symmetric complex 2 was found to be 
disordered, as were the ethyl arms of the diethylether ligand. In each case two orientations were identified, and only the non-hydrogen atoms of the major occupancy orientations were refined anisotropically. The structure of complex 4 was found to contain two crystallographically independent molecules (I and II) with essentially identical geometries (see Fig. 4 in the paper, and Figs. S3 and S5 below); the r.m.s. fit of the full-occupancy non-hydrogen atoms of the two complexes is ca. $0.14 \AA$. The $\mathrm{C}(14)$ and $\mathrm{C}(26)$ isopropyl groups in molecule $\mathbf{I}$, and the $\mathrm{C}\left(14^{\prime}\right)$ and $\mathrm{C}\left(56^{\prime}\right)$ isopropyl groups in molecule II were found to be disordered. In each case two orientations were identified, and only the non-hydrogen atoms of the major occupancy orientations were refined anisotropically. The absolute structure of $\mathbf{4}$ could not be unambiguously determined by either $R$-factor tests $\left[R_{1}{ }^{+}=0.0614, R_{1}^{-}=0.0618\right]$ or by use of the Flack parameter $\left[x^{+}=+0.35(9), x^{-}=+0.65(9)\right]$, and in fact the data suggests that the crystal studied was a partial racemic twin. The structure of complex $\mathbf{1 0}$ revealed disorder in the $\mathrm{C}(16)$ tert-butyl and $\mathrm{C}(38)$ ethyl units; in each case two orientations were identified, and only the non-hydrogen atoms of the major occupancy orientation were refined anisotropically. 


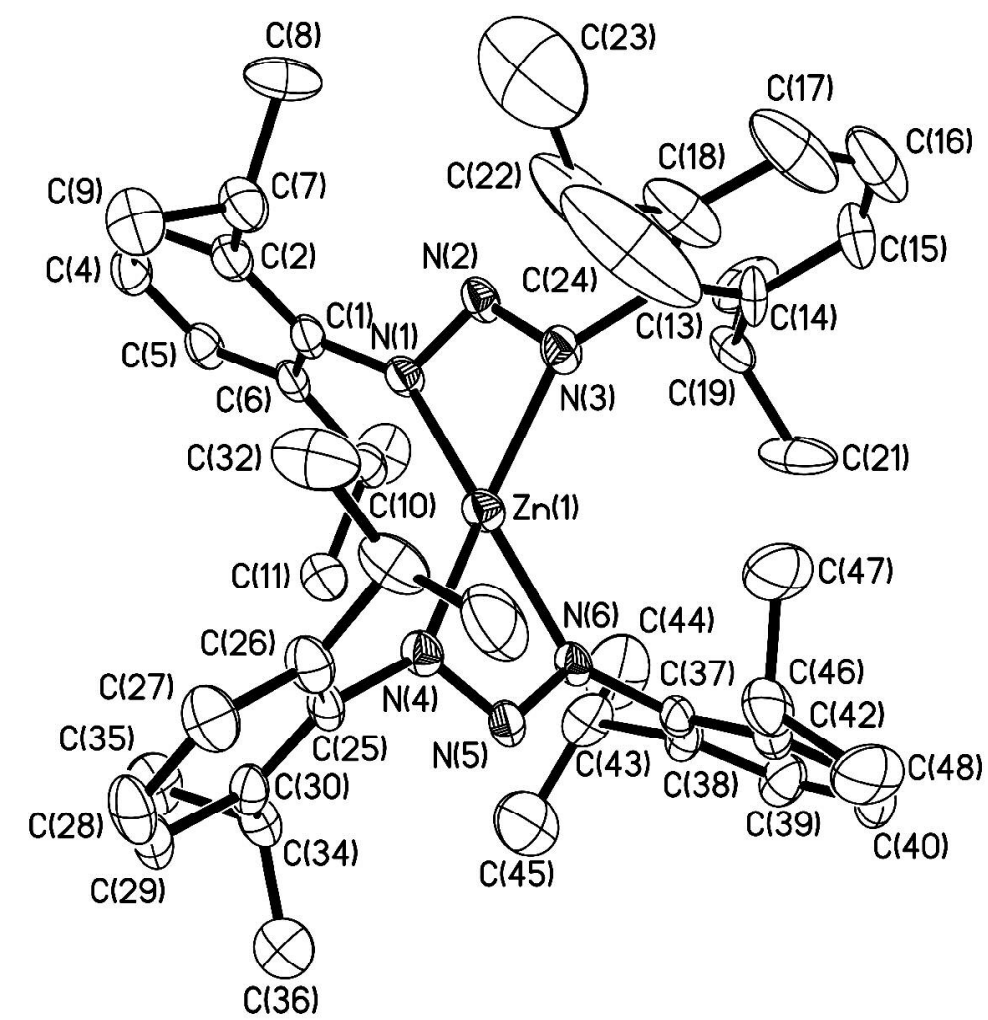

Figure S1. The molecular structure of complex 1 (40\% probability ellipsoids).

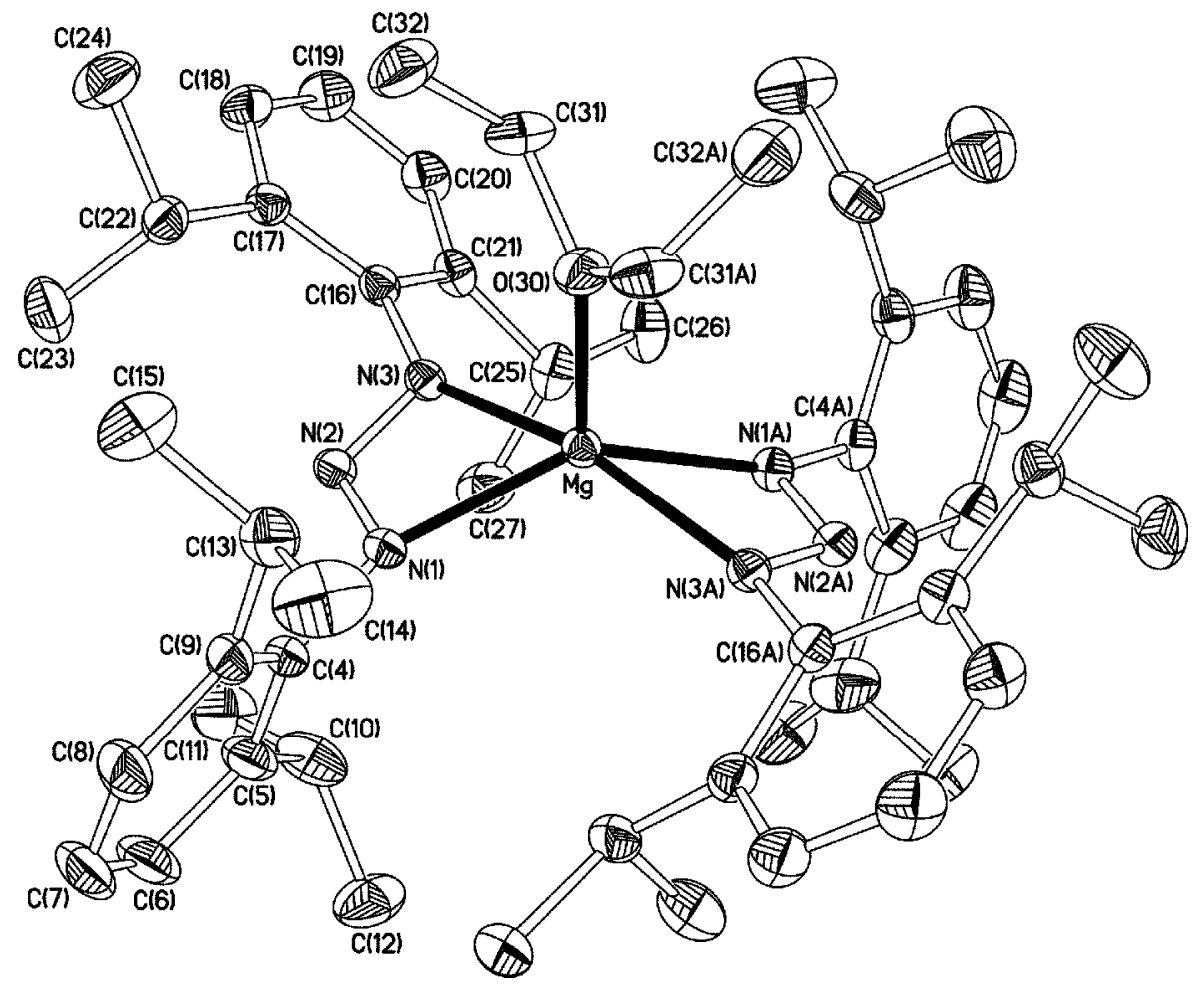

Figure S2. The molecular structure of the $C_{2}$-symmetric complex 2 (30\% probability ellipsoids). 


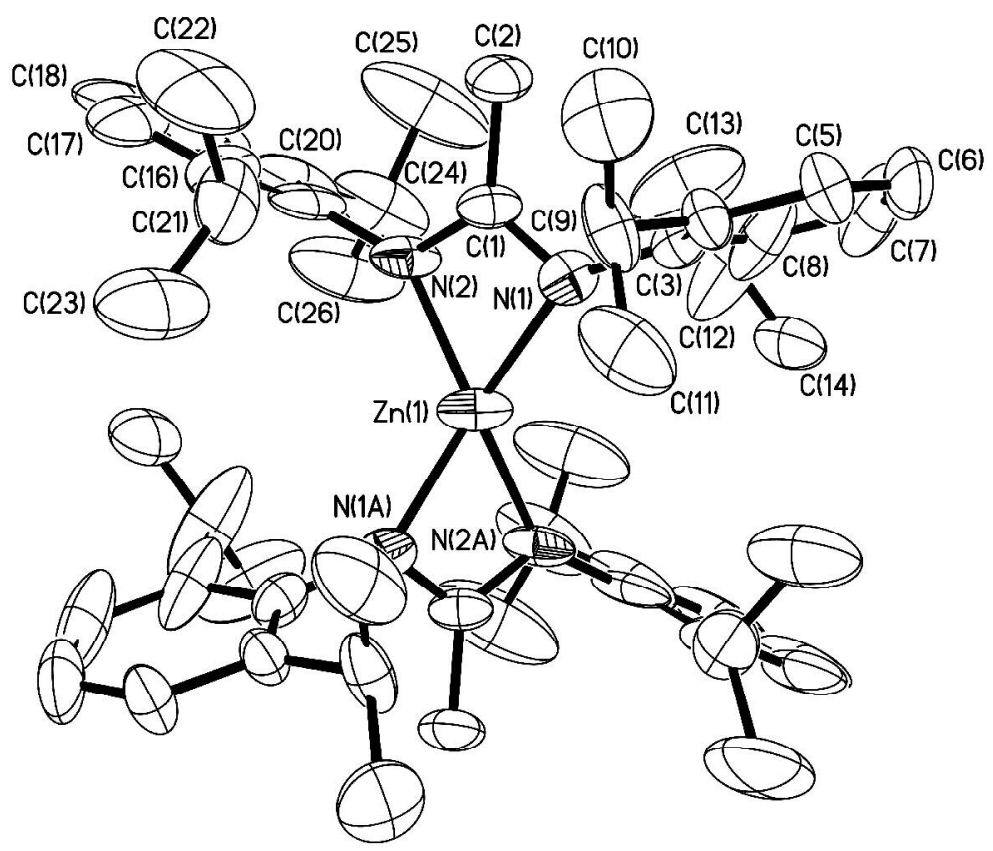

Figure S3. The molecular structure of complex 3 (40\% probability ellipsoids).

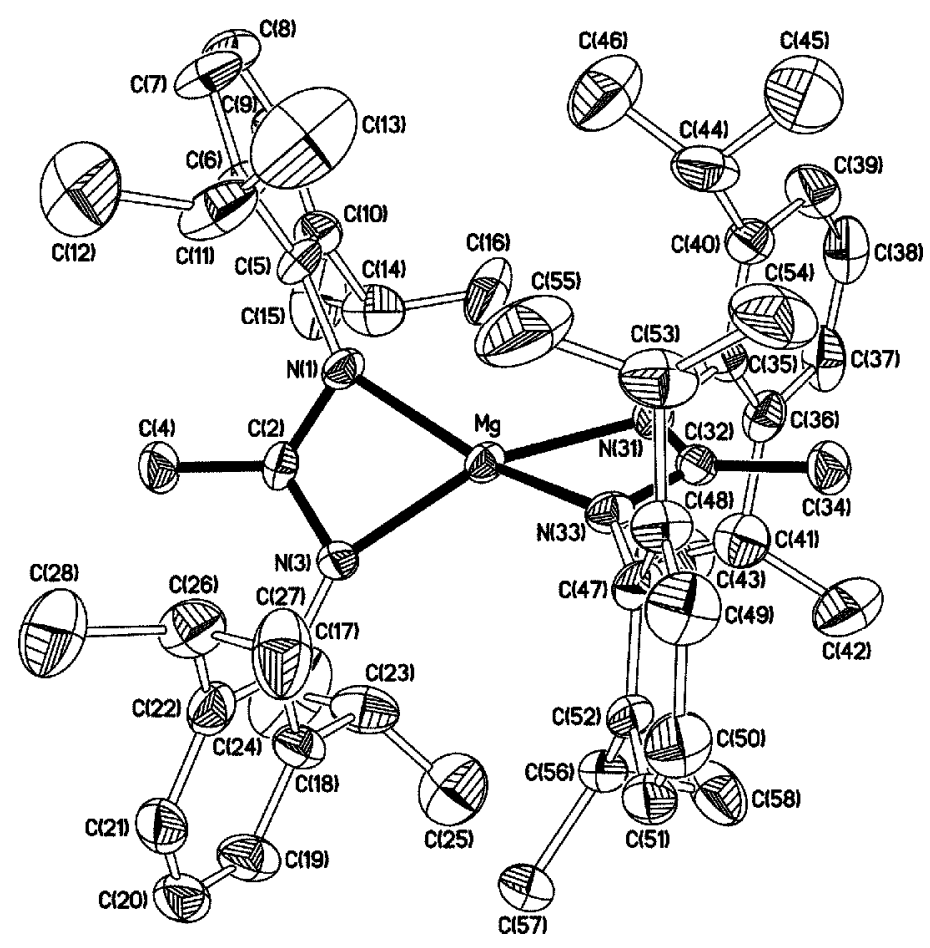

Figure S4. The molecular structure of one (I) of the two independent complexes present in the crystals of $\mathbf{4}$ (30\% probability ellipsoids). 


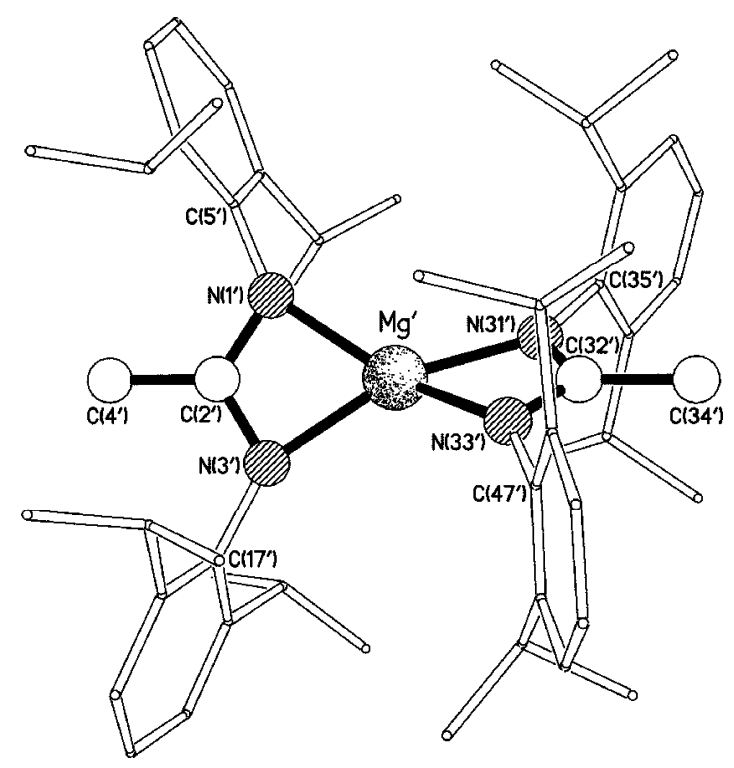

Figure S5. The molecular structure of one (II) of the two independent complexes present in the crystals of 4 .

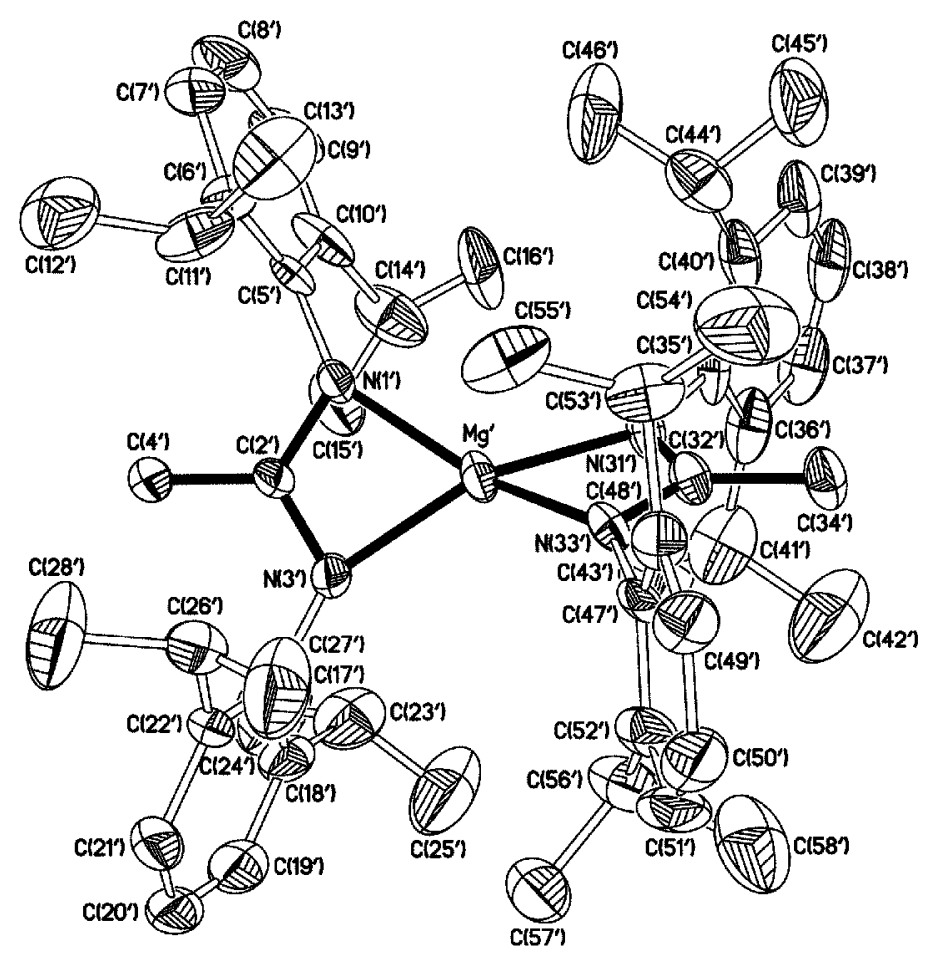

Figure S6. The molecular structure of one (II) of the two independent complexes present in the crystals of $\mathbf{4}$ (30\% probability ellipsoids). 


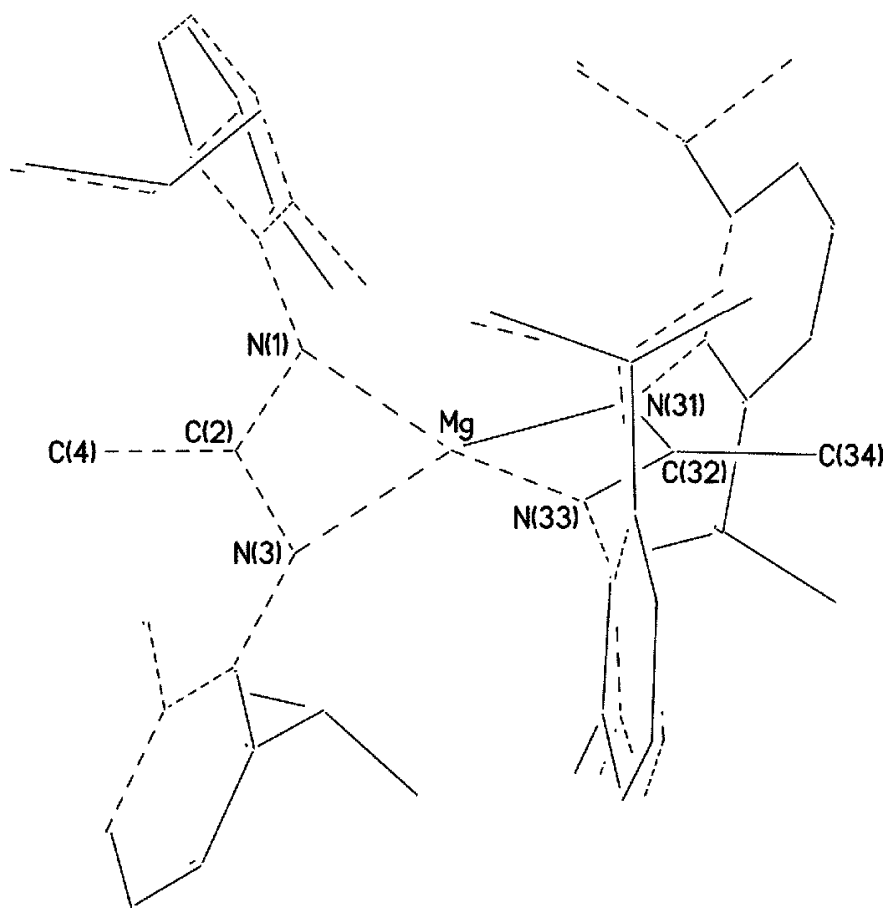

Figure S7. Overlay of the two independent complexes (I and II) present in the crystals of $\mathbf{4}$ (30\% probability ellipsoids). The r.m.s. fit of all the full occupancy nonhydrogen atoms of the two complexes is $c a .0 .14 \AA$.

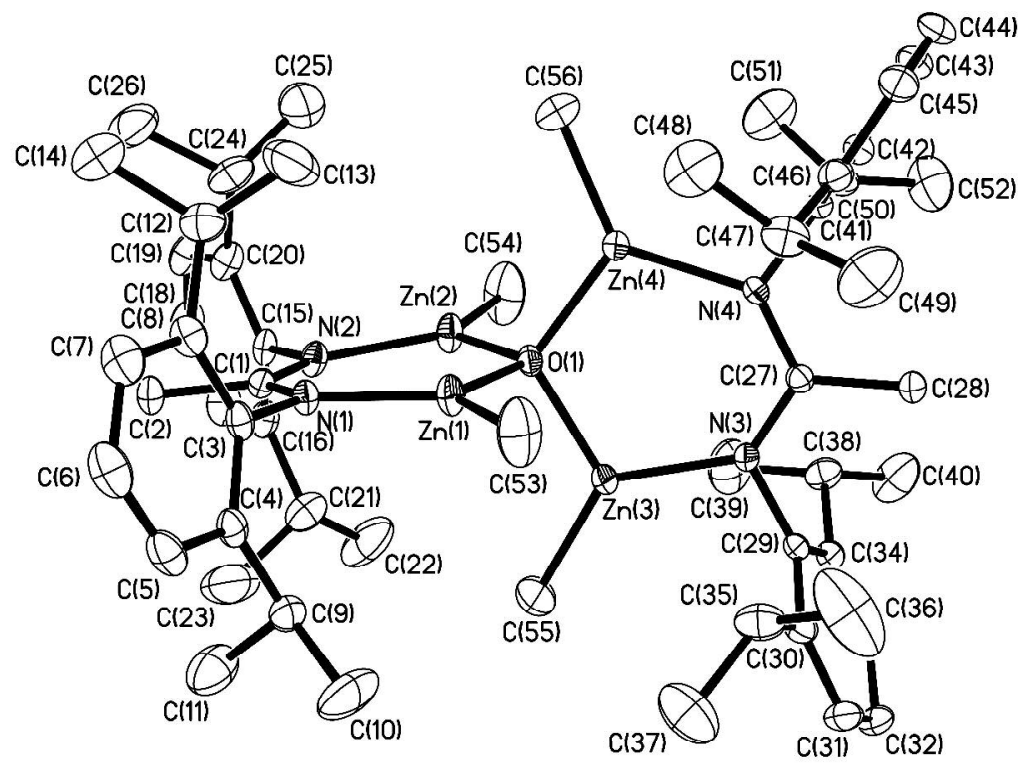

Figure S8. The molecular structure of complex 5 (40\% probability ellipsoids) 


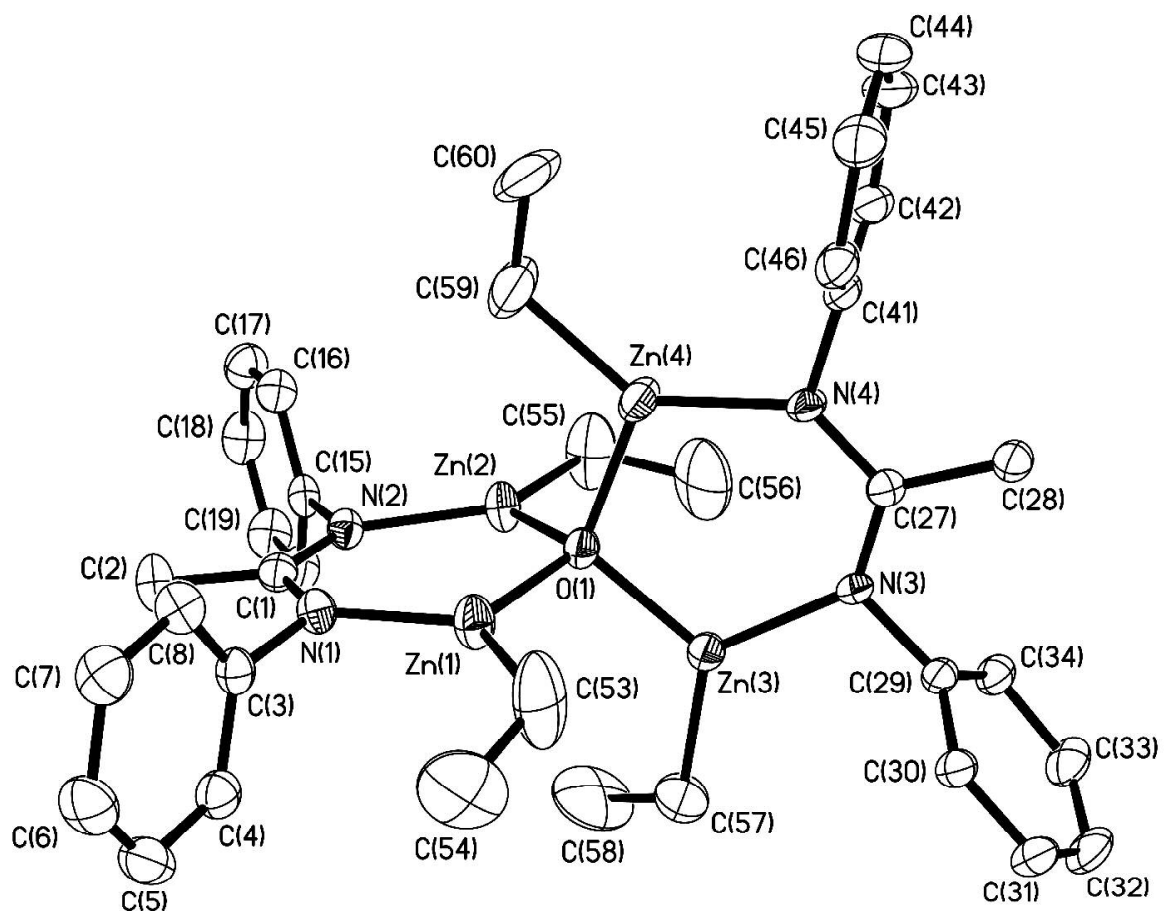

Figure S9. The molecular structure of one (molecule I) of the two independent complexes present in the crystals of $\mathbf{6}$ with iso-propyl groups and minor Et group disorder at $\mathrm{Zn}(4)$ omitted for clarity (50\% probability ellipsoids).

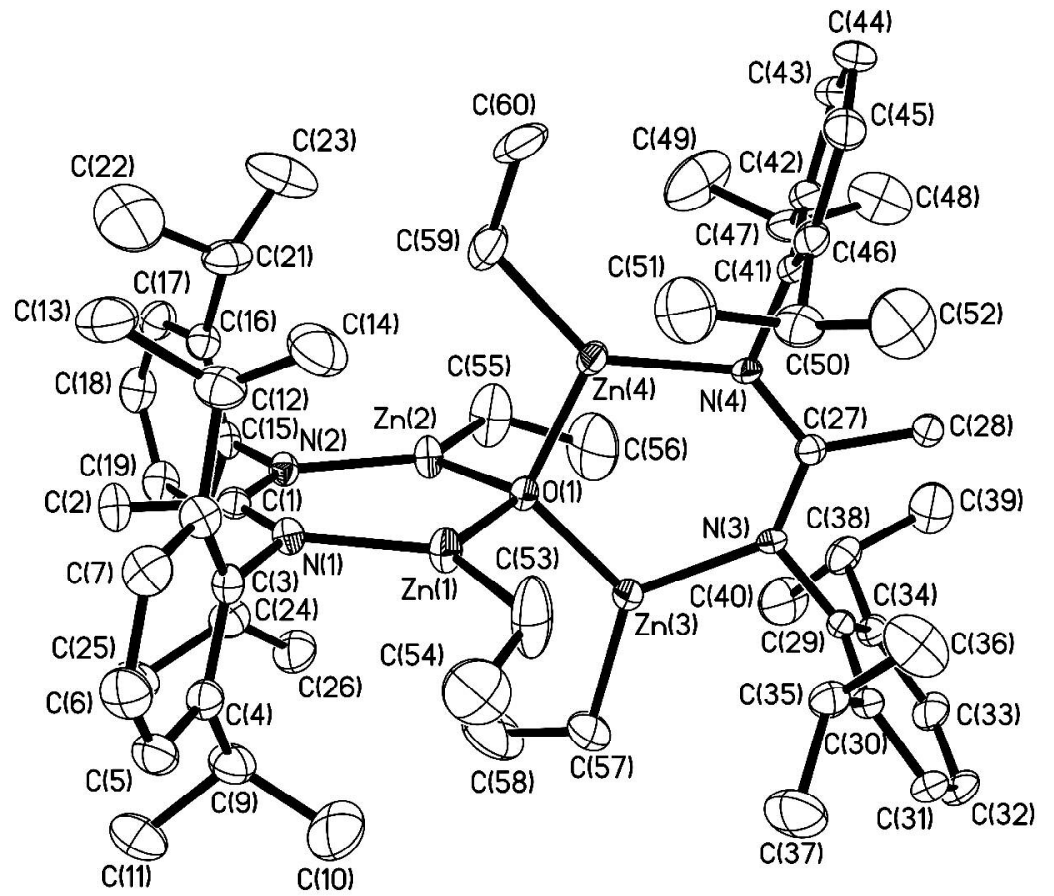

Figure S10. The molecular structure of one (molecule I) of the two independent complexes present in the crystals of 6 (40\% probability ellipsoids). 


\section{The molecular structure of complex 6:}

The unit cell of complex $\mathbf{6}$ contains two molecules [molecules 6-I and 6-II, containing $\mathrm{Zn}(1)-\mathrm{Zn}(4)$ and $\mathrm{Zn}(5)-\mathrm{Zn}(8)$ respectively]. As there are no significant difference in the bond parameters between 6-I and 6-II (Table S1), only molecule 6-I is shown in Figures S9 and S10. In the following discussion the data quoted refers to 6-I whilst the respective data for $\mathbf{6}-\mathbf{- I I}$ are listed in square parentheses. As observed for $\mathbf{5}$, the ethyl derivative $\mathbf{6}$ also possesses a slightly distorted tetrahedral geometry around the $\mathrm{O}$ atom with $\mathrm{Zn}-\mathrm{O}-\mathrm{Zn}$ angles ranging between 102.80(7) [106.65(8)] and 115.21(8) ${ }^{\circ}$ [111.27(7) $\left.{ }^{\circ}\right]$. Both $\mathrm{Zn}_{2} \mathrm{~N}_{2} \mathrm{CO}$ planes are again coplanar (to within $0.005 \AA\{\mathrm{Zn}(1)$, $\mathrm{Zn}(2)\}$ and $0.009 \AA\{\mathrm{Zn}(3), \mathrm{Zn}(4)\})[0.007 \AA\{\mathrm{Zn}(5), \mathrm{Zn}(6)\} ; 0.011 \AA\{\mathrm{Zn}(7)$, $\mathrm{Zn}(8)\}$ ]. Zn-O and $\mathrm{Zn}-\mathrm{N}$ bond lengths are comparable to those observed in $\mathbf{5}$ ( $\mathrm{Zn}-\mathrm{O}$ : $1.9529(16)-1.9619(16) \AA)[1.9444(16)-1.9667(16) \AA] ; \mathrm{Zn}-\mathrm{N}: 1.9659(19)-$ $1.9932(18) \AA[1.9674(19)-1.9780(18) \AA])$. 
Table S1. Selected bond lengths $(\AA)$ and angles $\left(^{\circ}\right)$ for both independent complexes (6-I and 6-II) present in the crystals of 6.

$\begin{array}{lcclcc} & \mathbf{6 - I} & \mathbf{6 - I I} & & \mathbf{6}-\mathbf{I} & \text { 6-II } \\ \mathrm{Zn}(1)-\mathrm{N}(1) & 1.9818(19) & 1.9741(19) & \mathrm{Zn}(2)-\mathrm{N}(2) & 1.9659(19) & 1.9674(19) \\ \mathrm{Zn}(3)-\mathrm{N}(3) & 1.9932(18) & 1.9743(19) & \mathrm{Zn}(4)-\mathrm{N}(4) & 1.9663(19) & 1.9780(18) \\ \mathrm{Zn}(1)-\mathrm{O}(1) & 1.9613(16) & 1.9625(16) & \mathrm{Zn}(2)-\mathrm{O}(1) & 1.9619(16) & 1.9527(16) \\ \mathrm{Zn}(3)-\mathrm{O}(1) & 1.9529(16) & 1.9667(16) & \mathrm{Zn}(4)-\mathrm{O}(1) & 1.9614(16) & 1.9444(16) \\ \mathrm{N}(1)-\mathrm{C}(1) & 1.332(3) & 1.331(3) & \mathrm{N}(2)-\mathrm{C}(1) & 1.324(3) & 1.326(3) \\ \mathrm{N}(3)-\mathrm{C}(27) & 1.326(3) & 1.333(3) & \mathrm{N}(4)-\mathrm{C}(27) & 1.336(3) & 1.321(3) \\ \mathrm{Zn}(1)-\mathrm{C}(53) & 1.966(3) & 1.961(3) & \mathrm{Zn}(2)-\mathrm{C}(55) & 1.961(3) & 1.974(3) \\ \mathrm{Zn}(3)-\mathrm{C}(57) & 1.967(3) & 1.970(3) & \mathrm{Zn}(4)-\mathrm{C}(59) & 1.969(6) & 1.956(3) \\ \mathrm{Zn}(1)-\mathrm{O}(1)-\mathrm{Zn}(2) & 109.99(7) & 111.27(7) & \mathrm{Zn}(1)-\mathrm{O}(1)-\mathrm{Zn}(3) & 107.69(8) & 108.95(7) \\ \mathrm{Zn}(1)-\mathrm{O}(1)-\mathrm{Zn}(4) & 111.34(8) & 110.15(8) & \mathrm{Zn}(2)-\mathrm{O}(1)-\mathrm{Zn}(3) & 115.21(8) & 106.65(8) \\ \mathrm{Zn}(2)-\mathrm{O}(1)-\mathrm{Zn}(4) & 102.80(7) & 108.85(8) & \mathrm{Zn}(3)-\mathrm{O}(1)-\mathrm{Zn}(4) & 109.80(7) & 110.94(7) \\ \mathrm{N}(1)-\mathrm{Zn}(1)-\mathrm{O}(1) & 109.78(7) & 110.92(7) & \mathrm{N}(2)-\mathrm{Zn}(2)-\mathrm{O}(1) & 113.44(7) & 110.51(7) \\ \mathrm{N}(3)-\mathrm{Zn}(3)-\mathrm{O}(1) & 111.83(7) & 110.22(7) & \mathrm{N}(4)-\mathrm{Zn}(4)-\mathrm{O}(1) & 111.81(7) & 111.41(7) \\ \mathrm{N}(1)-\mathrm{Zn}(1)-\mathrm{C}(53) & 132.12(11) & 132.08(11) & \mathrm{N}(2)-\mathrm{Zn}(2)-\mathrm{C}(55) & 131.23(11) & 129.77(12) \\ \mathrm{N}(3)-\mathrm{Zn}(3)-\mathrm{C}(57) & 126.39(11) & 131.28(11) & \mathrm{N}(4)-\mathrm{Zn}(4)-\mathrm{C}(59) & 136.1(2) & 125.03(11) \\ \mathrm{N}(1)-\mathrm{C}(1)-\mathrm{N}(2) & 120.8(2) & 120.6(2) & \mathrm{N}(3)-\mathrm{C}(27)-\mathrm{N}(4) & 120.5(2) & 120.6(2) \\ \mathrm{C}(53)-\mathrm{Zn}(1)-\mathrm{O}(1) & 118.07(11) & 117.00(11) & \mathrm{C}(55)-\mathrm{Zn}(2)-\mathrm{O}(1) & 115.31(11) & 119.71(12) \\ \mathrm{C}(57)-\mathrm{Zn}(3)-\mathrm{O}(1) & 121.65(11) & 118.48(10) & \mathrm{C}(59)-\mathrm{Zn}(4)-\mathrm{O}(1) & 111.5(2) & 123.45(11) \\ \mathrm{N}(1)-\mathrm{C}(1)-\mathrm{C}(2) & 118.6(2) & 120.4(2) & \mathrm{N}(2)-\mathrm{C}(1)-\mathrm{C}(2) & 120.6(2) & 118.9(2) \\ \mathrm{N}(3)-\mathrm{C}(27)-\mathrm{C}(28) & 120.8(2) & 118.7(2) & \mathrm{N}(4)-\mathrm{C}(27)-\mathrm{C}(28) & 118.71(19) & 120.6(2) \\ \mathrm{C}(1)-\mathrm{N}(1)-\mathrm{C}(3) & 118.93(19) & 119.12(19) & \mathrm{C}(1)-\mathrm{N}(2)-\mathrm{C}(15) & 119.92(19) & 119.16(19) \\ \mathrm{C}(27)-\mathrm{N}(3)-\mathrm{C}(29) & 119.59(18) & 118.45(19) & \mathrm{C}(27)-\mathrm{N}(4)-\mathrm{C}(41) & 119.18(19) & 120.15(18) \\ & & & & & \end{array}$




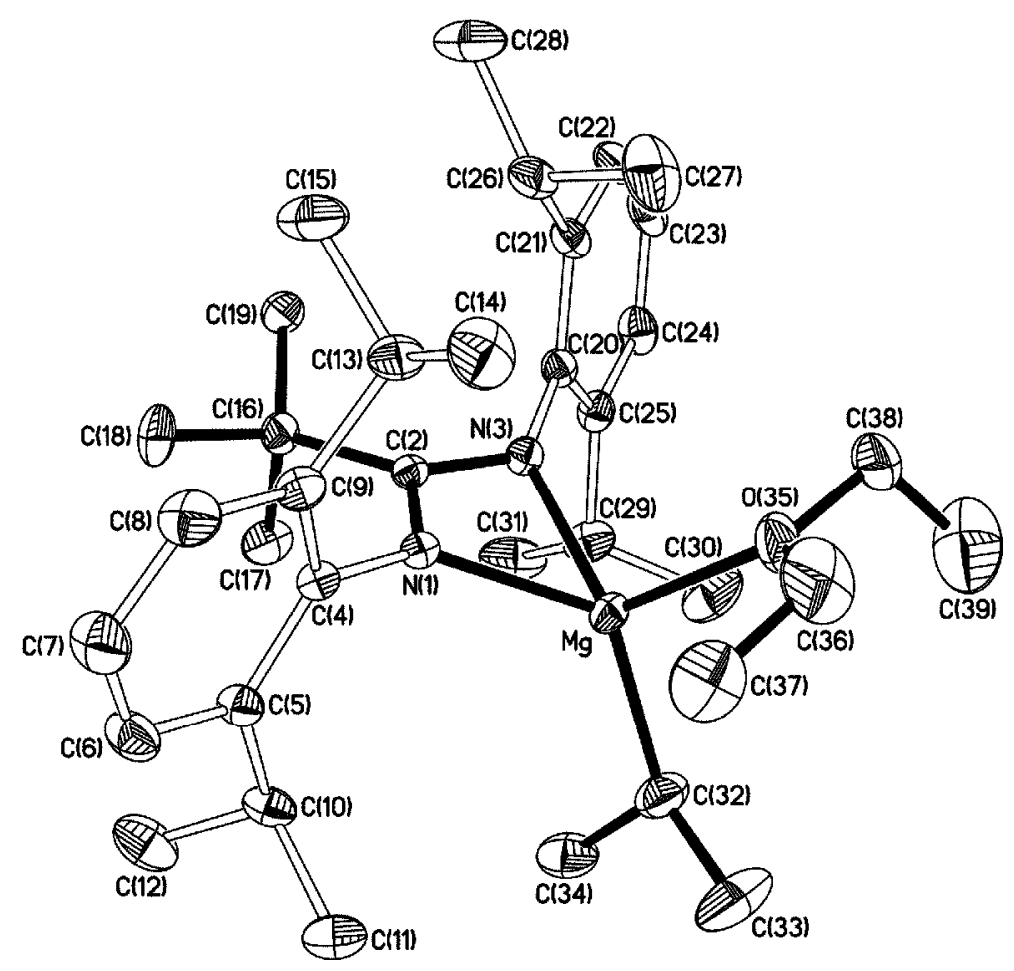

Figure S11. The molecular structure of $\mathbf{1 0}$ (30\% probability ellipsoids). 
Table S2. Crystal Data, Data Collection and Refinement Parameters for compounds 1, 2, 3, 4, 5, 6, 8 and 10.

\begin{tabular}{|c|c|c|c|c|c|c|c|c|}
\hline Compound & 1 & 2 & 3 & 4 & 5 & 6 & 8 & 10 \\
\hline Formula & $\mathrm{C}_{48} \mathrm{H}_{68} \mathrm{~N}_{6} \mathrm{Zn}$ & $\mathrm{C}_{52} \mathrm{H}_{78} \mathrm{~N}_{6} \mathrm{OMg}$ & $\mathrm{C}_{52} \mathrm{H}_{74} \mathrm{~N}_{4} \mathrm{Zn}$ & $\mathrm{C}_{52} \mathrm{H}_{74} \mathrm{~N}_{4} \mathrm{Mg}$ & $\mathrm{C}_{56} \mathrm{H}_{88} \mathrm{~N}_{4} \mathrm{OZn}_{4} \cdot 0.5 \mathrm{C}_{7} \mathrm{H}_{16}$ & $\mathrm{C}_{60} \mathrm{H}_{94} \mathrm{~N}_{4} \mathrm{OZn}$ & $\begin{array}{l}\mathrm{C}_{58} \mathrm{H}_{86} \mathrm{Cl}_{2} \mathrm{~N}_{4} \mathrm{Zn} \\
2\end{array}$ & $\mathrm{C}_{36} \mathrm{H}_{60} \mathrm{~N}_{2} \mathrm{OMg}$ \\
\hline$M$ & 794.45 & 827.51 & 820.52 & 779.46 & 1142.87 & 1148.87 & 1040.94 & 561.17 \\
\hline Temperature /K & $150(2)$ & $173(2)$ & $150(2)$ & $203(2)$ & $150(2)$ & $150(2)$ & $150(2)$ & $173(2)$ \\
\hline$\lambda / \AA$ & 0.71073 & 0.71073 & 0.71073 & 1.54178 & 0.71073 & 0.71073 & 0.71073 & 0.71073 \\
\hline Space group & $P 2_{1} / c$ & $C 2 / c$ & $C 222_{1}$ & $P 2_{1} 2_{1} 2_{1}$ & $P \overline{1}$ & $P \overline{1}$ & $P \overline{1}$ & $P 2_{1} / n$ \\
\hline$a / \AA$ & $14.215(2)$ & $12.9282(9)$ & $14.9634(16)$ & $14.8840(16)$ & $12.8498(11)$ & $12.2768(7)$ & $10.1119(7)$ & $13.4181(10)$ \\
\hline$b / \AA$ & $15.554(3)$ & $18.0227(11)$ & $20.060(2)$ & $16.8533(10)$ & $15.8773(18)$ & $19.3412(11)$ & $10.8336(7)$ & $15.7537(12)$ \\
\hline$c / \AA$ & $22.558(4)$ & $22.1648(11)$ & $16.4976(18)$ & $40.169(3)$ & $16.1078(17)$ & $26.9551(15)$ & $14.8162(10)$ & $16.9038(12)$ \\
\hline$\alpha /{ }^{\circ}$ & 90 & 90 & 90 & 90 & $100.399(11)$ & $100.699(2)$ & $105.994(2)$ & 90 \\
\hline$\beta /^{\circ}$ & $107.670(3)$ & $96.194(5)$ & 90 & 90 & $90.376(9)$ & $101.245(2)$ & $102.370(2)$ & $97.116(6)$ \\
\hline$\gamma /{ }^{\circ}$ & 90 & 90 & 90 & 90 & $104.661(8)$ & $95.880(2)$ & $107.057(2)$ & 90 \\
\hline$U / \AA^{3}$ & $4752.3(14)$ & $5134.3(5)$ & $4952.0(9)$ & $10076.3(14)$ & $3122.4(6)$ & $6104.3(6)$ & $1412.67(16)$ & $3545.7(5)$ \\
\hline$Z$ & 4 & 4 & 4 & 8 & 2 & 4 & 1 & 4 \\
\hline$D_{\mathrm{c}} / \mathrm{g} \mathrm{cm}^{-3}$ & 1.110 & 1.071 & 1.101 & 1.028 & 1.216 & 1.250 & 1.224 & 1.051 \\
\hline$\mu / \mathrm{mm}^{-1}$ & 0.55 & 0.08 & 0.53 & 0.56 & 1.56 & 1.59 & 0.982 & 0.08 \\
\hline$R\left(F, F^{2}>2 \sigma\right)$ & 0.0904 & 0.0899 & 0.0771 & 0.0613 & 0.0322 & 0.0383 & 0.0287 & 0.0994 \\
\hline$R_{\mathrm{w}}\left(F^{2}\right.$, all data $)$ & 0.2136 & 0.2335 & 0.1937 & 0.1601 & 0.0872 & 0.0994 & 0.0738 & 0.2618 \\
\hline
\end{tabular}




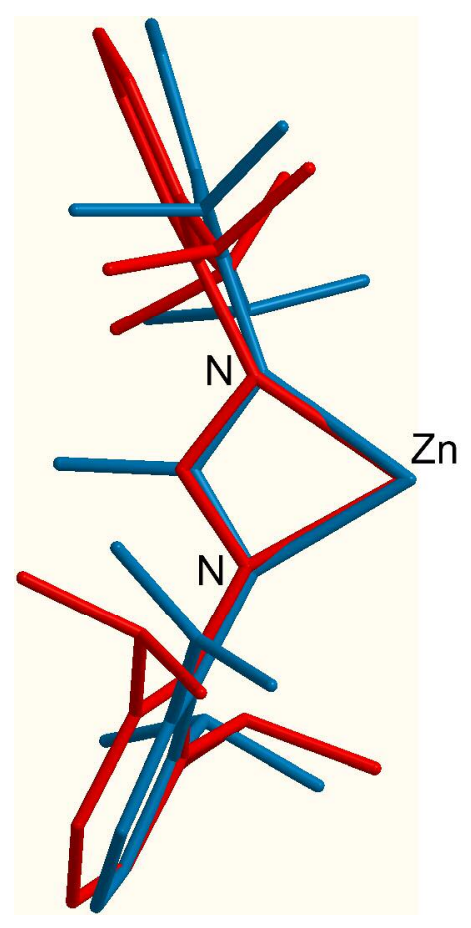

Figure S12. Overlay diagram of one of the $\mathrm{L}^{1} \mathrm{Zn}$ fragments of complex 1 (red) with one of the $\mathrm{L}^{2} \mathrm{Zn}$ fragments of complex 3 (blue), showing increased $\mathrm{Zn}-\mathrm{N}-\mathrm{C}_{\text {-ipso }}$ angles in 1.

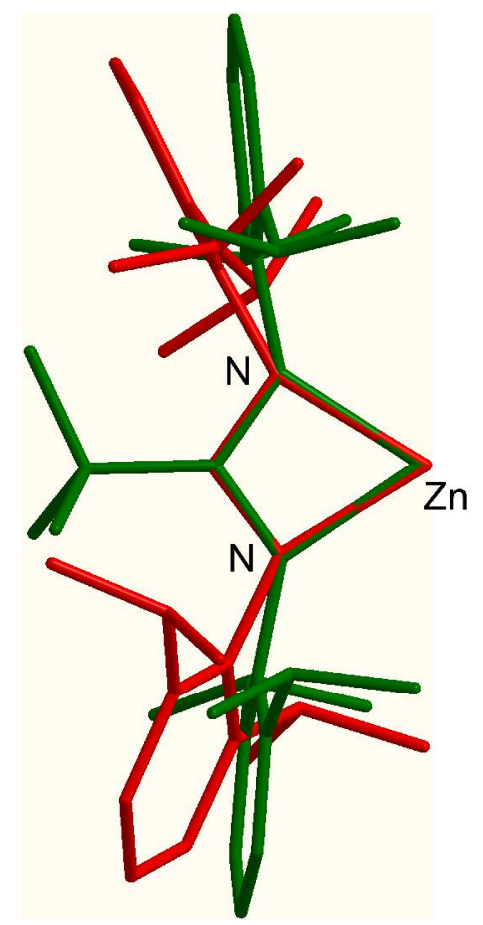

Figure S13. Overlay diagram of one of the $\mathrm{L}^{1} \mathrm{Zn}$ fragments of complex $\mathbf{1}$ (red) with the $\mathrm{L}^{3} \mathrm{Zn}$ fragment of complex $\mathbf{8}$ (green), showing increased $\mathrm{Zn}-\mathrm{N}-\mathrm{C}_{\text {-ipso }}$ angles in $\mathbf{1}$. 


\section{References}

S1. SMART and SAINT software for CCD diffractometers, Bruker AXS Inc., Madison, WI, 2001.

S2. Sheldrick, G. M., SHELXTL user manual, version 6.10, Bruker ACS Inc., Madison, WI, 2000. 